\title{
Dwa oblicza emancypacji podmiotu
}

\section{Streszczenie}

Artykuł poświęcony jest dwuznaczności zjawiska emancypacji ludzkiego podmiotu, która to dwuznaczność jest jednym z wymiarów kontyngencji człowieka. Poprzez dwuznaczność rozumie się tu dwa rozbieżne i sprzeczne ze sobą sposoby bycia, które emancypacja podmiotu może ewokować: z jednej strony sposób bycia polegający na twórczym samoprzewyższeniu, z drugiej na pozbawionym twórczego pierwiastka utrwalaniu siebie. Punktem wyjścia analiz jest przywołanie dwu ujęć tej dwuznaczności: 1) zarysowanego przez Taylora rozdźwięku pomiędzy romantyczną ideą autentyczności a współczesną samorealizacją oraz 2) różnicy pomiędzy nadczłowiekiem i ostatnim człowiekiem w myśli Nietzschego. W artykule przedstawione zostały przyczyny tej dwuznaczności w ujęciu egzystencjalno-ontologicznym (Heidegger) i psychoanalitycznym (Freud). Zarówno popędowa, jak i egzystencjalno-ontologiczna struktura ludzkiego podmiotu przesądza o nie w pełni przewidywalnym (a więc kontyngentnym) kierunku jego samorozwoju, który niezależnie od woli podmiotu może pójść w dwie zasadniczo odmienne strony.

Słowa kluczowe: kontyngencja człowieka, emancypacja podmiotu, struktura egzystencjalno-ontologiczna, struktura popędowa.

\section{Wprowadzenie}

Chciałbym przyjrzeć się w tym artykule dwuznaczności nowoczesnej emancypacji ludzkiego podmiotu, będącej jednym z wymiarów kontyngencji człowieka. Poprzez dwuznaczność rozumiem tu dwa rozbieżne i kłócące się ze sobą sposoby

Piotr Augustyniak, Uniwersytet Ekonomiczny w Krakowie, Katedra Filozofii, 31-510 Kraków, ul. Rakowicka 27, e-mail: paugusty@o2.pl 
bycia, które może ewokować emancypacja. Pierwszy z nich polega na twórczym samoprzewyższeniu, drugi na pozbawionym twórczego pierwiastka utrwalaniu siebie. Punktem wyjścia moich analiz jest przywołanie dwóch przykładowych ujęć tej dwuznaczności: zarysowanego przez Charlesa Taylora rozdźwięku pomiędzy romantyczną ideą autentyczności a współczesną samorealizacją oraz różnicy pomiędzy „nadczłowiekiem” i „ostatnim człowiekiem” w myśli Fryderyka Nietzschego. W dalszej części artykułu przedstawione zostaną przyczyny tej dwuznaczności w ujęciu egzystencjalno-ontologicznym (Martin Heidegger) i psychoanalitycznym (Zygmunt Freud). Jak się okazuje, zarówno egzystencjalno-ontologiczna, jak i popędowa wykładnia ludzkiego podmiotu prowadzi do wniosku, że to, w którym z dwu wskazanych kierunków potoczy się indywidualny rozwój, jest nie w pełni przewidywalne (a więc jest kontyngentne). Rozwój ten, niezależnie od woli podmiotu, może pójść w dwie zasadniczo odmienne strony, wyznaczone przez dwa opisane w tym artykule sposoby bycia. Większe jest jednakże prawdopodobieństwo, że pójdzie w stronę samorealizacji, co też w praktyce częściej się zdarza.

\section{Taylor}

Charles Taylor stawia w Etyce autentyczności tezę, że nowoczesna, mająca swe źródło w oświeceniu, emancypacja podmiotu doprowadziła współcześnie do sposobu bycia, na który składają się trzy zjawiska. Pierwszym i dla naszych rozważań kluczowym jest ideologia i praktyka karykaturalnej samorealizacji, skrajnie egocentrycznej i hedonistycznej. Drugim dominacja techniki i, szerzej, rozumu instrumentalnego oraz ich zgubny (alienujący i atomizujący) wpływ na ludzką egzystencję, co tylko pogłębia karykaturalną samorealizację. Trzecim zaś - będącym de facto efektem dwu pozostałych - kryzys współczesnej demokracji. Zajęty sobą i swoimi technicznymi gadżetami nowoczesny podmiot nie jest bowiem skory do przejawiania postaw obywatelskich. Zupełnie nie poczuwa się do odpowiedzialności za jakość społecznego życia i za losy państwa. Chce mieć święty spokój i zagwarantowane prawo oraz środki do bycia i zajmowania się sobą. Formalnie rzecz biorąc, przybliża to władzę - wybieraną co prawda wciąż demokratycznie i utrzymującą struktury (lub już tylko fasady) demokratycznego ustroju - do Tocqueville'owskiego łagodnego despotyzmu.

Nie będą to rządy terroru i ucisku jak w dawnych czasach. Władza będzie dobrotliwa i paternalistyczna. Może nawet zachowa formę demokratyczną - z okresowymi wyborami. W istocie jednak wszystko będzie sterowane przez „potężną i opiekuńczą władzę", nad którą lud nie będzie właściwie sprawował kontroli [Taylor 2002, s. 16]. 
Zdaniem Ch. Taylora emancypacja nowoczesnego podmiotu nie musiałaby potoczyć się w stronę opisanego, głęboko niepokojącego, sposobu bycia. Pojawia się ona bowiem na gruncie moralnego ideału autentyczności, który narodził się w dobie romantyzmu i który wyznacza również inny możliwy sposób bycia nowoczesnej, emancypującej się podmiotowości. Bez wchodzenia w szczegóły myśl Taylora jest następująca: dzisiejsza samorealizacja, a więc współczesny, egocentryczny indywidualizm, nie jest realizacją ideału autentyczności, ale rozwijając się na jego gruncie, stanowi jego wypaczenie. Są zatem możliwe zdaniem Taylora dwa rodzaje nowoczesnego indywidualizmu: indywidualizm autentyczności i nieautentyczności, będący karykaturą tego pierwszego. Ten drugi już znamy. Czym różniłby się od niego indywidualizm wiernie realizujący ideał autentyczności? Jego sednem jest poszukiwanie i odnajdywanie przez podmiot w sobie samym odpowiedzi na pytanie, jak żyć.

Taki oto ideał moralny w wielkiej sile otrzymaliśmy w spadku. Przypisuje on kluczową rolę moralną nawiązaniu przez każdego z nas swoistego kontaktu z samym sobą - z naszą własną wewnętrzną naturą - który możemy zawsze zgubić [...]. Co więcej, rola owego wewnętrznego kontaktu wzrasta niepomiernie dzięki wprowadzeniu zasady oryginalności: głos każdego z nas ma do powiedzenia coś własnego. [...] nie jestem w stanie znaleźć poza sobą jakiegokolwiek wzorca do naśladowania. Taki wzorzec mogę odnaleźć jedynie we własnym wnętrzu [Taylor 2002, s. 35].

To, czy człowiek spełni się i odnajdzie sens życia, zależy właśnie od tego, czy odnajdzie go we własnym wnętrzu. Ten wzniosły i autentyczny kształt samorealizacji miałby swój wzorzec w formule sztuki, rozumianej jako pęd do wyrażenia siebie. To właśnie odnajdując prawdę w sobie i dokonując jej ekspresji w swoim życiu, podmiot osiąga autentyczność. Taylor argumentuje, że należy odróżnić tak pojętą autentyczność od Nietzscheańskiej wizji twórczości. Taylor uważa bowiem, że to twórcze samowyrażenie dokonywać się może tylko w już uprzednio istniejącym horyzoncie znaczenia (a więc w horyzoncie takich lub innych zobiektywizowanych wartości) oraz w przestrzeni dialogu z innymi podmiotami. O ile dobrze rozumiem Taylora, jego zdaniem Nietzsche jest odpowiedzialny za destrukcję tej idei autentyczności i przesunięcie jej w kierunku spłyconej i karykaturalnej współczesnej samorealizacji. Nietzsche łączy bowiem twórcze samowyrażenie z przewartościowaniem wartości, które oznacza destrukcję wartości dotychczasowych (obiektywnych) i zastąpienie ich wartościami nowymi (czyli de facto ciągłą, że się tak wyrażę, wartościotwórczą aktywnością podmiotu). Zdaniem Taylora zatem Nietzsche przyczynia się w ten sposób do negacji aksjologicznego horyzontu społecznego życia.

[...] Ewolucja kultury „wysokiej” w kierunku swoistego nihilizmu, negacja wszelkich horyzontów znaczenia - ewolucja, która trwa już półtora stulecia. Kluczową 
postacią w tym procesie jest Nietzsche. [...] W istocie Nietzscheańska krytyka wszelkich „wartości” jako ustanowionych musi z natury rzeczy doprowadzić do dowartościowania i umocnienia antropocentryzmu. [...] W miarę jak owa [...] teoria przesiąka do popularnej kultury, [...] wzmacnia ona jeszcze bardziej egocentryczne formy zachowania [Taylor 2002, s. 61-62].

Gdyby się zgodzić z Taylorem, trzeba by uznać więc, że Nietzsche, wbrew swym intencjom, torował drogę „ostatniemu człowiekowi”, a więc właśnie współczesnemu, płytko i karykaturalnie samorealizującemu się podmiotowi. Oczywiście Taylor zdaje sobie sprawę, że na równi z Nietzschem, a pewnie i bardziej od niego, winne są temu obiektywne procesy cywilizacyjne związane z technicyzacją i konsumpcyjnym stylem życia, propagowanym przez neoliberalizm.

Do Nietzschego, którego stanowisko Taylor upraszcza, przejdę za chwilę. Zanim to zrobię, chciałbym podkreślić, że sposób bycia emancypującego się podmiotu oparty na idei autentyczności nie jest zdaniem Taylora tylko hipotetyczną możliwością, tkwiącą w tej idei, ale że jest to możliwość realna. Jest to sposób bycia, w którym podmiot realizuje siebie w horyzoncie wartości i dialogu z innymi. Ma żywą świadomość moralną i poczucie odpowiedzialności za wspólnotę. Taki indywidualizm oczywiście zdaniem Taylora niekiedy się pojawia, co dowodzi, że nie jest to idea sztucznie przez Taylora wykoncypowana, ale taka, która w świecie nowoczesnym już zaistniała.

Reasumując, Taylor rozróżnia i opisuje dwie odmienne formy realizacji nowoczesnej emancypacji. Pierwsza to masowa samorealizacja niskich lotów, skrajnie egocentryczna i zamknięta na twórczość, druga to twórcze wyrażenie siebie, pełne wrażliwości na kwestie moralne i społeczne.

\section{Nietzsche}

Charles Taylor zarzuca Fryderykowi Nietzschemu, że swoją wizją twórczej indywidualności otworzył drogę do rozpowszechnienia się w świecie indywidualnego sposobu bycia opartego na egocentrycznej samorealizacji. Tymczasem sam Nietzsche radykalnie krytykuje taki sposób bycia i wypracowuje dla niego alternatywę. W Przedmowie do Tako rzecze Zaratustra przeciwstawia dwie skrajnie różne odmiany wyemancypowanego podmiotu, są to „ostatni człowiek” i ,nadczłowiek”.

„Ostatni człowiek” wedle Zaratustry jest trwale niezdolny do sposobu bycia, który polegałby na autentycznie twórczym samorozwoju. Jego samorozwój jest pozorny, jest to samorealizacja, czyli nic innego niż realizowanie tego samego siebie w kolejnych sekwencjach czasu, a więc samoutrwalenie względnie samozachowanie. Autentycznie twórczy samorozwój polega zaś na przeciwieństwie samo- 
utrwalenia, czyli wznoszeniu się ponad siebie, przekraczaniu i przezwyciężaniu w sobie już zaistniałego, tego oto człowieka. Dlatego o „ostatnim człowieku” powiada on: „Biada! Nadchodzi czas, kiedy człowiek nie przerzuci już strzały swej tęsknoty poza człowieka" [Nietzsche 1999, s. 17].

„Ostatni człowiek” utożsamia skuteczne samoutrwalenie ze szczęściem, a ze względu na swoją w tym wprawę czuje się wynalazcą i posiadaczem szczęścia. „«Wynaleźliśmy szczęście» - mówią ostatni ludzie, mrugając oczami” [Nietzsche 1999, s. 18]. Jak konkretnie to szczęście wygląda? Przede wszystkim jest ono długowiecznością. Zaratustra powiada w tym kontekście, że „ostatni człowiek będzie żył najdłużej” [Nietzsche 1999, s. 18]. Receptą na długowieczność jest zaś wygoda i łatwość życia. Dlatego ludzie ci „opuścili okolice, gdzie twarde było życie" [Nietzsche 1999, s. 18]. Do tego należy dodać oszczędzanie się, czyli unikanie wysiłku, szczególnie w pracy, która z trudu powinna przemienić się w rozrywkę. „Pracują jeszcze, praca jest bowiem rozrywką. Ale dbają, by ich rozrywka nie nadwerężała" [Nietzsche 1999, s. 18]. Szczególnie istotne w tym zapewnianiu sobie szczęścia-trwałości jest dbanie o bezpieczeństwo, a więc unikanie jakichkolwiek zagrożeń. „Ostatni człowiek” powiada więc do siebie: „[...] ostrożność. Głupcem ten, kto jeszcze potyka się o kamienie czy ludzi” [Nietzsche 1999, s. 18]. Skrajną zaś, prewencyjną formą unikania zagrożeń jest dążenie do społeczeństwa eliminującego wszelką inność, a więc koniec końców do pełnej homogeniczności. Dlatego „ostatni ludzie” przestają się od siebie różnić - różnice pomiędzy nimi zanikają w wyniku ich zamierzonych działań. Upatrując swe szczęście w poszukiwaniu bezpieczeństwa, lądują w jednorodności, która ma objąć cały świat. Zachowując pozory różnorodności, rozpływają się w ogólnym „to samo”: „Każdy chce tego samego; każdy jest taki sam. Kto czuje inaczej, z własnej woli idzie do domu dla obłąkanych" [Nietzsche 1999, s. 18].

Nietzsche nie ma więc złudzeń, jak dalece pozorna jest twórczość ludzi skupionych na samorealizacji. Ponieważ jest to opis życia przystający doskonale do naszego świata, Nietzsche jest, podobnie jak Taylor, krytykiem nowoczesnej podmiotowości. Również jednak dla niego sposób bycia „ostatnich ludzi” jest pochodną wzniosłego ideału nowoczesnej emancypacji podmiotu - jego przerażającą realizacją. Przerażającą dlatego, że pozorną - przewrotnie doprowadzającą do zanegowania ruchu emancypacji. Kryjąca się za nią homogenizacja społeczna, zanegowanie i wykluczenie inności, czyni z „ostatniego człowieka” zwierzę stadne, resentymentalny tłum, jak to określił Ortega y Gasset [2002], ,zbuntowanych mas".

Nietzsche przeciwstawia tej egocentrycznej emancypacji, prowadzącej do swego zaprzeczenia, realizację zgoła odmienną. Reprezentuje ją „,nadczłowiek”. Jest on jednostką, której życie stanowi przeciwieństwo samozachowania. Wypełnia je bowiem ekstatyczne i transowe wykraczanie ponad siebie. Ciągłe przekraczanie 
siebie, czyli przezwyciężanie w sobie człowieka jako już osiągniętego, zdobytego przyczółka trwałości i znaczenia. „Będę was uczył nadczłowieka. Człowiek jest czymś, co trzeba przezwyciężać" - tak Nietzsche [1999, s. 12] streszcza swoje rozumienie tego sposobu bycia.

Tak rozumiany „nadczłowiek” jest podmiotem, który praktykuje radykalną i nieskłamaną emancypację. Jest burzycielem, który „burzy ich tablice wartości” [Nietzsche 1999, s. 24]. Wartości, które scalają zbiorowość, sprowadzają jednostkę do zależnego od siebie i wtórnego wobec siebie elementu. Postrzegany jest więc jako „obrazoburca”. Nie tylko wyłamuje się bowiem z takiej zbiorowości, ale zwraca się przeciwko niej jako temu, co tamuje i pacyfikuje ruch transgresji (samoprzezwyciężenia). Przezwyciężenie siebie, praktykowane przez „nadczłowieka", nie jest więc zniesieniem jednostki, ale właśnie jej wydobyciem ze społecznego ogółu, ustanowieniem jej radykalnie jednostkowej indywidualności.

Zdaniem Nietzschego radykalna i nieredukująca siebie do zbiorowego „to samo" indywidualność musi być wolna od dominacji samozachowawczej samorealizacji. A może być od niej wolna tylko jako podmiotowość zatracająca się w twórczości. Angażująca się w proces tworzenia, który Nietzsche przyrównuje do ekstatycznego lotu i tańca, a zarazem ekstremalnej wspinaczki, w czasie której do owej ekstazy mozolnie się dorasta w ruchu samoprzezwyciężenia. Tylko taka podmiotowość zyskuje autentyczną indywidualność, wykraczając poza granice bezpieczeństwa, zabezpieczania i utrwalania siebie (tutaj bowiem, podkreślmy raz jeszcze, zawsze kończy się triumfem unieważniającej indywidualność zbiorowości).

Różnica względem koncepcji Taylora jest tu ewidentna. Zarzuty Taylora pod adresem Nietzschego, które można byłoby streścić jako bliskie pokrewieństwo „,nadczłowieka” i „ostatniego człowieka”, Nietzsche zapewne by odwrócił. Z jego perspektywy bowiem to właśnie opisywana przez Taylora romantyczna podmiotowość pozornie tylko sprzeciwia się podmiotowości „ostatniego człowieka”. Jeśli bowiem, jak chce Taylor, otwiera się na już istniejący horyzont wartości, to z konieczności wkracza na drogę utrwalania, względnie przywracania zbiorowego status quo, a więc ewokuje podmiotowość, która nie tylko w ramach niezmiennego horyzontu wartości się samoutrwala, ale pracuje na rzecz relatywizującego indywidualność, zbiorowego „to samo”. Podobnie jest z romantyczną ideą indywidualności jako samowyrażenia. Sposób bycia, który wyrażać ma to, co jest zrazu ukrytą, ale jednak już obecną prawdą podmiotu, jest wszak niczym innym niż troską o realizację siebie w perspektywie samoutrwalenia.

Nietzsche w to miejsce proponuje indywidualne „tworzenie wartości”, bo tylko tak indywidualność może przezwyciężyć przemoc zbiorowości. Idei samowyrażenia przeciwstawia zaś ideę tworzenia siebie - twórczego stwarzania siebie wciąż na nowo, w ruchu ciągłego przekraczania i porzucania siebie już istniejącego. 
Na obiekcje Taylora można byłoby odpowiedzieć w tym kontekście w ten sposób, że „tworzenie wartości” przez taką nieutrwalającą się podmiotowość o tyle nie jest subiektywizmem, że nie pracuje na rzecz „konserwującego się” subiektu, ale na rzecz społecznej atmosfery twórczej zmiany.

W kontekście omawianego w tym artykule zagadnienia najistotniejsze jest jednak to, że obaj myśliciele rozróżniają dwie sprzeciwiające się sobie realizacje nowoczesnej idei emancypacji podmiotu. Jedną, która grzęźnie w płytkim egocentryzmie narcystycznego skupienia na sobie i jest de facto tej idei zaprzeczeniem, oraz drugą, będącą przede wszystkim możliwością, która jednak sporadycznie się realizuje jako autentyczna i twórcza indywidualność. Powstaje pytanie, co decyduje o pójściu jedną lub drugą drogą oraz co przesądza, że jest to najczęściej, choć nie zawsze, pierwsza z dróg. Nie jest to raczej kwestia w pełni świadomego wyboru jednostki. Również emancypacyjne warunki społeczne, zdominowane przez masową popkulturę, które co prawda popychają jednostkę w kierunku nietwórczej samorealizacji, nie wydają się sprawy całkowicie wyjaśnić. Skoro więc nie jest to kwestia ani świadomego samookreślenia, ani pełnej determinacji społecznej, wyjaśnienie musi kryć się w obrębie konstytutywnej struktury ludzkiej egzystencji.

\section{Heidegger}

W istocie sprawa zaczyna się wyjaśniać, jeśli spojrzeć na ową niejednoznaczność nowoczesnej emancypacji podmiotu z perspektywy Heideggerowskiej analityki egzystencjalno-ontologicznej. Martin Heidegger, opisując zasadniczą strukturę Dasein jako odnoszenie się do bycia, pisze: „Jestestwo [Dasein - P.A.] to byt, który nie tylko występuje pośród innego bytu. Wyróżnia je ontycznie raczej to, że temu bytowi w jego byciu chodzi o samo to bycie" [Heidegger 1994, s. 17]. Przy czym odniesienie to realizuje się na dwa sposoby. Pierwszy z nich, nazywany przez Heideggera niewłaściwym, jest zrazu i zwykle nieuchronny i polega na odniesieniu do bycia na sposób ucieczki. Ponieważ bycie Dasein jest skończone, śmiałe wyjście naprzeciw niego oznacza konfrontację z własną skończonością, czyli uprzedzające natknięcie się na własną śmierć. Dlatego Dasein odruchowo odnosi się do bycia tak, aby z nim nie mieć do czynienia. To również jest odniesienie, ale właśnie w modus ucieczki i uniku. Nie chcemy konfrontować się ze śmiercią. Nie chcemy o niej myśleć, wybieramy więc zaprzątnięcie codziennymi sprawami. Heidegger nazywa to „przeciętną powszedniością” Dasein. „Także w niej, i to w samym modus niewłaściwości [...] chodzi jestestwu w pewien sposób o jego bycie, [...] choćby tylko w modus ucieczki przed nim i zapomnienia 
o nim" [Heidegger 1994, s. 61]. Jest to jego popadanie w błahość codziennych spraw i zatracanie się w ich biegu.

Sytuacja ta ma oczywisty wymiar samozachowawczy. Codzienność ma bowiem wedle Heideggera charakter łańcucha spraw-celów, które łączą się ze sobą jako kolejne ,ze względu na”. Przy czym - podobnie jak dla Arystotelesa [1996] żadne konkretne dobro nie jest dobrem najwyższym - dla Heideggera żadne ukonkretnione jako zewnętrzna rzecz lub sprawa „ze względu na” nie jest ostateczne. Ich łańcuch biegnie tak długo, aż powróci do Dasein. To właśnie ono jest tym „ze względu na", tym celem, który uruchamia codzienne dążenie Dasein od jednej sprawy do następnej.

Sam jednak całokształt powiązania sprowadza się ostatecznie do pewnego „do czego", [...] które samo nie jest bytem o sposobie bycia czegoś poręcznego w obrębie świata, lecz bytem, którego bycie jest określane jako bycie w świecie. [...] „Ze względu na” dotyczy [...] zawsze bycia jestestwa, któremu w jego byciu $\mathrm{z}$ istoty $o$ samo to bycie chodzi [Heidegger 1994, s. 120].

Innymi słowy, łańcuch kolejnych „ze względu na” zawsze dzieje się w horyzoncie troski Dasein o własne bycie. Podobnie, wedle Arystotelesa [1996] poszczególne, względne dobra są dla człowieka dobrami ze względu na dobro najwyższe, do którego prowadzą, a którym jest szczęście, czyli spełnienie człowieka.

Wariantami tego niewłaściwego, zrazu i zwykle nieuchronnego, i jak się okazało - samozachowawczego, utrwalającego Dasein sposób bycia, jest popadanie w Się i gadaninę, które razem wzięte oznaczają bezmyślność, pustosłowie oraz kierowanie się opiniami i zwyczajami innych. Jest w tym wszystkim eskapizm i nietwórczość. Ucieczka przed własnym byciem oznacza bowiem niepodejmowanie otwierających się w nim możliwości, niewychodzenie im naprzeciw, a dokładnie podejmowanie ich na sposób niepodejmowania, swego rodzaju bierności.

Przeciwieństwem niewłaściwego jest sposób bycia nazywany przez Heideggera właściwym. Jest on również odniesieniem do własnego bycia, ale takim odniesieniem, które nie jest ucieczką przed nim, lecz wydobywaniem się z codziennego upadania. Tym, co uaktywnia ów sposób bycia, jest trwoga, dotknięcie nicości względnie skończoności bycia, które konfrontuje Dasein z tym, że jest „byciem-ku-śmierci”. „Trwoga przed śmiercią stawia jestestwo wobec siebie samego jako zdanego na nieprześcignioną możliwość" [Heidegger 1994, s. 357]. W tej perspektywie zainteresowanie własnym byciem nie jest już prozaicznym utrwalaniem siebie, wytwarzającym łańcuch codziennego świata, w którym się można zatracić, ale jest jedyną w swoim rodzaju intensyfikacją siebie, wzmożonym projektowaniem siebie, odpowiadaniem za własne bycie i przed własnym byciem, czyli wzięciem za nie twórczej odpowiedzialności, odpowiedzialności za nadawanie mu kształtu, podejmowanie otwierających się w nim możliwości. 
Bycie Dasein nigdy nie sprowadza się tylko do jednego z tych egzystencjalnych modusów, ale jest, jeśli można tak powiedzieć, oscylacją. Codziennym punktem wyjścia jest niewłaściwość, kiedy się bowiem budzi nasza przytomność siebie, budzi się ona zawsze ze snu zatracenia w codzienności. Ale codzienna niewłaściwość nigdy nie znika, przeciwnie, wypełnia większość życia. Cyklicznie się z niej budzimy i cyklicznie w nią zapadamy. Można powiedzieć, że ta oscylacja, wymykająca się woli decyzyjnej człowieka, jest naszym kontyngentnym uwarunkowaniem. I stanowi doskonałą podpowiedź, skąd bierze się opisana przeze mnie dwukierunkowość nowoczesnej emancypacji podmiotu. To, co jest rytmem życia człowieka, czyli oscylacyjność sposobów bycia Dasein, przekłada się na emancypację, która na przemian w życiu człowieka oznaczać może egocentryczne samoutrwalenie, będące przedłużeniem niewłaściwego sposobu bycia, oraz twórcze tworzenie siebie, będące przedłużeniem właściwego sposobu bycia. $\mathrm{Na}$ skalę społeczną owa jednostkowa oscylacja przekłada się jako praktykowanie dwu alternatywnych form emancypacji: dominującej, skupionej na samorealizacji, i elitarnej, skupionej na twórczym samoprzewyższeniu. Przy czym dominować musi ta pierwsza, ponieważ w perspektywie indywidualnej czasowości zdecydowanie dominuje niewłaściwy sposób bycia.

\section{Freud}

Do podobnych wniosków prowadzi odwołanie się do teorii popędowej Zygmunta Freuda. Jak wiadomo, teoria ta ewoluowała, nie będę jednak odnosił się do jej przekształceń. Dla potrzeb niniejszego artykułu wystarczy bowiem, jeśli odwołam się do jej pierwszego sformułowania. Podstawowa dystynkcja, którą czyni Freud na tym etapie rozwoju swojej teorii, to rozróżnienie popędów samozachowawczych i popędów seksualnych. Pierwsze z nich Freud nazywa również popędami ego.

Pierwotnie nazwaliśmy tak wszystkie nie znane nam bliżej tendencje popędowe, które udało się oddzielić od skierowanych na obiekt popędów seksualnych i które doprowadzały [...] do konfliktów z popędami seksualnymi, których wyrazem jest libido [Freud 2005, s. 55].

Owe popędy samozachowawcze, jak sama ich nazwa wskazuje, popychają podmiot do działań samozachowawczych, chroniących jego integralność, przedłużających jego trwanie, przeciwdziałających unicestwiającemu naporowi świata, sile entropii, a przede wszystkim miłosnemu pędowi za obiektem, który - nieokiełznany - zagraża podmiotowości samounicestwieniem.

Drugie, z nazwy związane z seksualnością, mają znaczenie bliższe platońskiemu Erosowi niż przyrodniczej sile służącej li tylko prokreacji. Nie jest to 
biologiczny pęd przedłużenia gatunku, ale poszukiwania przyjemności, które w ramach rozwoju wtórnie, choć nieuchronnie łączy się ze sferą genitalną i tym samym zaczyna pracować na rzecz rozrodczości.

Czym są ,popędy seksualne”, dowiedzieliśmy się z ich stosunku do płci i rozmnażania. Porzuciliśmy potem tę nazwę, gdy zostaliśmy dzięki wynikom psychoanalizy zmuszeni do rozluźnienia jej związków z rozmnażaniem. [...] Popęd seksualny przekształcił się w erosa [Freud 2005, s. 55].

Z platońskim Erosem łączy ten przyjemnościowy pęd przede wszystkim to, że natrafiając na opór ze strony otoczenia (Freud powiada: realności), wkracza na ścieżkę sublimacji. Czyli będąc zrazu skierowany na podstawowe przyjemności seksualne, przekierowuje się na obiekty zastępcze (takie jak sztuka, moda, świat idei, podróże czy działalność charytatywna) i otwiera się na specyficzne przyjemności obcowania z nimi. $Z$ naszej perspektywy istotne jest to, że tak zdefiniowane popędy seksualne są motorem twórczości i ciekawości podmiotu, które każą mu wyjść poza strzeżone popędami samozachowawczymi własne granice, zanurzyć się w świecie, zapomnieć się w nim, rozdać siebie jego powabom, zatracić się w pogoni za jego atrakcjami.

Myśl Freuda zmierza w takim kierunku, że podmiotowość może funkcjonować tylko w oparciu o oba rodzaje popędów. Brak popędów samozachowawczych musiałby doprowadzić do zupełnej destrukcji podmiotu, który zostałby wyniszczony przez ekstatyczną siłę popędów seksualnych - idąc za nimi bez żadnych wewnętrznych oporów, roztrwoniłby samego siebie. Brak popędów seksualnych doprowadziłby zaś do zupełnego zamknięcia się na świat, do niemożliwości nawiązania z nim kontaktu, do autystycznego zasklepienia się w sobie i wrogiego, agresywnego bronienia się przed jakimkolwiek oddziaływaniem z zewnątrz. Słowem, do izolacji tak radykalnej, że również niosącej unicestwienie. Podmiot ma możliwość życia tylko jako układ zarazem odgraniczony od świata i w nim zanurzony, wychodzący ku niemu. Czyli jako wzajemna gra obu rodzajów popędów.

Gra ta jednak nigdy nie jest statyczną równowagą sił. Jest to układ dynamiczny, w którym oba rodzaje popędowych sił wzajemnie się zwalczają i sobie przeciwdziałają. Dlatego w psychice danego podmiotu ich wzajemne relacje mogą się różnie ułożyć, przechodząc w taką lub inną z reguły trwałą i trudną do zmiany tendencję. Możliwy jest więc podmiot, w którym zdecydowanie górę biorą popędy samozachowawcze, lub taki, w którym dominują popędy seksualne. Zależy to od wielu czynników, m.in. od siły i pozycji superego, które przeciwstawia się pędowi do przyjemności.

Bez wchodzenia głębiej w szczegóły teorii Freuda widać, że na jej gruncie również da się wyjaśnić dwa zasadnicze kierunki emancypacji podmiotu, wiążąc je z dwoma możliwymi układami relacji pomiędzy obiema siłami popędowymi. 
A ponieważ występowanie jednego lub drugiego układu zależne jest od czynników, na które podmiot za sprawą swych świadomych wyborów ma ograniczony wpływ (takich jak choćby siła superego, zależnego głównie od modelu wychowania i społecznej presji), potwierdza się wyjściowa teza artykułu, że kształt nowoczesnej emancypacji podmiotu ma kontyngentny charakter. Co więcej, na gruncie teorii Freuda, podobnie jak na gruncie analityki egzystencjalnej Heideggera, staje się zrozumiałe, dlaczego najczęściej emancypacja ta, wbrew oświeceniowym założeniom, które leżą u jej podstaw, przyjmuje kształt egocentrycznej samorealizacji. Powodem jest to, że popędy samozachowawcze częściej biorą górę, co jest uwarunkowane m.in. silną pozycją w nowoczesnym świecie kulturowych zakazów i norm, wzmacniających superego, a więc wzmagających represję popędów seksualnych. Nawet życie erotyczne, choćby najbardziej bujne, nie jest tu (w świecie nowoczesnym) ekstazą, ale formą rozrywki i pielęgnacji zdrowia służącą samorealizacji podmiotu.

\section{Podsumowanie}

Reasumując, odwołanie do filozoficznych przemyśleń Charlesa Taylora i Fryderyka Nietzschego pozwoliło nam ukazać dwa warianty emancypacji podmiotu, która jest jednym z podstawowych procesów w obrębie cywilizacji nowoczesnej. Podmiot, wchodząc na ścieżkę emancypacji, albo skierowuje się w stronę indywidualnej samorealizacji o charakterze zasadniczo samozachowawczym, albo - co zdarza się zdecydowanie rzadziej - obiera drogę twórczego samorozwoju, o charakterze wyraźnie ekstatycznym. Odwołanie do myśli Martina Heideggera i Zygmunta Freuda pozwoliło nam ukazać z jednej strony ontologiczno-egzystencjalne, a z drugiej popędowe podłoże obu tych możliwości. Obie drogi są możliwe, ale o podążeniu przez podmiot jedną z nich tylko w ograniczonym stopniu decyduje jego świadomy wybór.

\section{Literatura}

Arystoteles [1996], Etyka nikomachejska, przeł. D. Gromska [w:] tenże, Dzieła wszystkie, t. 5, PWN, Warszawa.

Freud S. [2005] Poza zasada przyjemności, przeł. J. Prokopiuk, PWN, Warszawa.

Heidegger M. [1994], Bycie i czas, przeł. B. Baran, PWN, Warszawa.

Nietzsche F. [1999], To rzekt Zaratustra. Ksiązka dla wszystkich i dla nikogo, przeł.

S. Lisiecka, Z. Jaskuła, PIW, Warszawa.

Ortega y Gasset J. [2002], Bunt mas, przeł. P. Niklewicz, Muza, Warszawa.

Taylor Ch. [2002], Etyka autentyczności, przeł. A. Pawelec, Znak, Kraków. 


\section{Two Faces of the Emancipation of the Subject}

(Abstract)

The article discusses the duality of the phenomenon of emancipation of the human subject; this duality is one of the dimensions of the contingency of man. By duality I understand two discrepant and contradictory modes of being, which the emancipation of the subject can evoke. The first mode is being that consists in rising above the self through creativity, while the second is solidifying oneself, which lacks a creative element. The starting point for this analysis is a review of two approaches to this duality: 1) the dissonance between the romantic idea of authenticity and the contemporary self-actualisation, outlined by Taylor; and 2) the difference between the superman and the last man in Nietzsche's thought. The second part of the article presents the reasons for this duality from an existential and ontological perspective (Heidegger) and from a psychoanalytical perspective (Freud). Both the drive-based structure and the existential-ontological structure of the human subject determine the not fully predictable (i.e. contingent) direction of self-development, which - regardless of the subject's will can take two fundamentally different routes.

Keywords: contingency of man, emancipation of subject, existential-ontological structure, drive-based structure. 